\title{
Komunikasi Antarpribadi Antara Anggota Keluarga dalam Mendukung Penderita Autoimun (ODAMUN)
}

Veronika Trimardhany

Institut Komunikasi dan Bisnis LSPR, Jakarta, Indonesia

\begin{abstract}
ABSTRAK
ODAMUN adalah singkatan dari Orang dengan penderita autoimun. Penyakit autoimun adalah penyakit dimana sistem kekebalan yang terbentuk salah mengidentifikasi benda asing, dimana sel, jaringan atau organ tubuh manusia justru dianggap sebagai benda asing sehingga dirusak oleh antibodi. Jadi adanya penyakit autoimmun tidak memberikan dampak peningkatan ketahanan tubuh dalam melawan suatu penyakit, tetapi justru terjadi kerusakan tubuh akibat kekebalan yang terbentuk. Oleh karena itu dukungan dari anggota keluarga menjadi sangat penting untuk penderita autoimun. Komunikasi dalam keluarga juga dapat diartikan sebagai kesiapan untuk membicarakan dengan terbuka setiap masalah dalam keluarga, baik yang menyenangkan maupun yang menyedihkan, hal ini para anggota akan siap menyelesaikan masalah-masalah yang dihadapi dengan saling membicarakan satu sama lain dengan kesabaran, kejujuran dan keterbukaan. Komunikasi yang terjadi antara lain komunikasi antarpribadi antar anggota keluarga. Metodologi dalam penelitian ini menggunakan Kualitatif Deskriptif dengan pendekatan Fenomenologi dengan menguraikan pengalaman empat orang penderita autoimun dengan didampingi keluarganya. Hasil yang didapat adalah mereka melakukan komunikasi antarpribadi secara efektif dengan faktor-faktor: keterbukaan, empati, sikap mendukung, sikap positif dan kesetaraan. Dari kelima faktor yang paling menonjol adalah sikap mendukung dari penderita, hal inilah yang selalu diharapkan oleh penderita untuk memotivasi untuk sembuh. Keluhan awal dari penderita autoimun adalah Panas sekujur badan, sariawan, merah ruam-ruam, namun setiap penderita keluhannya berbedabeda namun yang paling sering lemas dan tak bertenaga. Solusi dari penderita adalah berobat ke dokter, mengelola stress dan selalu berpikir positif dalam segala situasi, sedangkan dari anggota keluarga dalam memberikan dukungan yaitu mendampingi saat keluhan datang dan langsung membawa ke rumah sakit.
\end{abstract}

Kata kunci: Pendererita, autoimun, motivasi, komunikasi antarpribadi, efektif.

\section{Interpersonal Communication Between Family Members in Supporting Autoimmune Sufferers (ODAMUN)}

\begin{abstract}
ODAMUN stands for People with autoimmune patients. Autoimmune disease is a disease where the immune system that is formed incorrectly identifies foreign objects, where cells, tissues or organs of the human body are actually considered foreign objects so that they are damaged by antibodies. So the presence of autoimmune disease does not have an impact on increasing the body's resistance to a disease, but instead occurs damage to the body due to the formed immunity. Therefore, support from family members becomes very important for autoimmune sufferers. Communication in the family can also be interpreted as a readiness to talk openly about every problem in the family, both pleasant and sad, this is where members will be ready to solve the problems they face by talking to each other with patience, honesty and openness. Communication that occurs, among others, interpersonal
\end{abstract}


communication between family members. The methodology in this study uses descriptive qualitative with a phenomenological approach by describing the experiences of four people with autoimmune disorders accompanied by their families. The results obtained are that they carry out interpersonal communication effectively with the following factors: openness, empathy, supportive attitude, positive attitude and equality. Of the five factors, the most prominent is the supportive attitude of the sufferer, this is what the sufferer always hopes to motivate to recover. Initial complaints from autoimmune sufferers are fever all over the body, canker sores, red rashes, but each sufferer has different complaints, but most of them are weak and powerless. The solution for sufferers is to go to the doctor, manage stress and always think positively in all situations, while family members provide support, namely accompanying when complaints come and immediately taking them to the hospital.

Keywords: sufferers, autoimmune, motivation, interpersonal communication, effective

\section{PENDAHULUAN}

ODAMUN adalah singkatan dari orang dengan penderita autoimun. Penyakit autoimun merupakan penyakit yang menyerang sistem kekebalan tubuh manusia yang biasa terjadi pada kaum wanita. Autoimun merupakan gangguan sistem kekebalan tubuh akibat gagalnya pertahanan kestabilan kondisi tubuh, sehingga sistem imun menyerang tubuh yang sehat dianggap sebagai benda asing yang harus dimusnahkan. Penyakit autoimun ini menyebabkan kerugian bagi organ tubuh manusia karena dapat merusak organ-organ sel yang masih sehat dalam tubuh seseorang. Contoh penyakit autoimun yang paling sering ditemukan diantaranya Artritis Reumatoid, Lupus Eritematosus Sistematik, Penyakit Seliak, Sindrom Sjorgen, Polomialgia Reumatika, Sklerosis Multipel, Spondilitis Ankilosa, Diabetes Tipe 1, Alopesia Areata, Radang Pembuluh Darah, Arteritis Temporalis dan lain sebagainya (Siloam Hospital, 13 Maret 2019).

Penyakit autoimun adalah penyakit dimana sistem kekebalan yang terbentuk salah mengidentifikasi benda asing, dimana sel, jaringan atau organ tubuh manusia justru dianggap sebagai benda asing sehingga dirusak oleh antibodi. Jadi adanya penyakit autoimun tidak memberikan dampak peningkatan ketahanan tubuh dalam melawan suatu penyakit, tetapi justru terjadi kerusakan tubuh akibat kekebalan yang terbentuk. Ada dua teori utama yang menerangkan mekanisme terjadinya penyakit autoimun. Pertama, autoimun disebabkan oleh kegagalan pada delesi DNA limfosit normal untuk mengenali antigen tubuh sendiri. Kedua, autoimun disebabkan oleh kegagalan regulasi normal sistem imunitas (yang mengandung beberapa sel imun yang mengenali antigen tubuh sendiri namun mengalami supresi). Terjadinya kombinasi antara faktor lingkungan, faktor genetik dan tubuh sendiri berperan dalam ekspresi penyakit autoimun. Beberapa contoh penyakit autoimun tersebut antara lain adalah Rheumatoid arthritis (RA), Systemic Lupus Erythematosus (SLE), Antiphospholipid Syndrome (APS) (Endang, 2013).

Gejala autoimun ini mirip dengan penyakit lainnya seperti nyeri sendi, mudah lelah, rambut rontok, sering sariawan, demam yang tidak beraturan, dan sebagainya. Menurut dr. Iris Rengganis pakar autoimun di Jakarta, mengatakan bahwa: "autoimun disebabkan berbagai factor, diantaranya keturunan (genetik) dan gaya hidup serta lingkungan. Faktor gaya hidup 
dan lingkungan sangat dominan menjadi autoimun. Namun penyakit ini dapat dicegah atau dikontrol dengan penerapan pola hidup sehat menyeluruh" (Gatra.com, 2019).

Setidaknya 5.000 orang di Indonesia merupakan penyintas atau penderita autoimun (autoimmune). Jumlah pastinya belum diketahui dan angka 5.000 ini berdasarkan penyintas yang terdata di Marisza Cardoba Foundation (MCF). Marisza Cardoba Foundation (MCF) adalah wadah pelayanan untuk mengidap autoimun yang didirikan oleh Marisza Cardoba (penyintas autoimun), bersama Dr. dr. Andika Rachman Sp.PD, KHOM. Menurut Marisza, dinyatakan bahwa belum ada data pasti jumlah penyintas autoimun, karena belum tingginya kesadaran (awareness) masyarakat serta pemerintah belum memiliki data yang valid (Gatra.com, 2019). Selanjutnya dikatakan, minimnya pengetahuan masyarakat di Indonesia akan penyakit mematikan tersebut merupakan salah satu penyebab belum adanya data valid dari jumlah penyintas. Padahal, diduga kuat penderitanya bisa mencapai jutaan bahkan puluhan juta orang di Indonesia. Sedangkan untuk di Amerika Serikat (AS), jumlahnya mencapai 50 juta orang, atau sekitar 15,5\% dari total jumlah penduduk. Pakar autoimun juga sebagai ketua Dewan Pembina MCF, Dr. dr. Iris Rengganis Sp.PD, mengungkapkan bahwa $80 \%$ penyintas autoimun adalah perempuan usia produktif (Gatra.com, 2019).

Merujuk pada penelitian sebelumnya oleh Diantin dan teman-temannya, penelitiannya bertujuan untuk mengetahui angka kejadian pasien anak dengan penyakit autoimun di RSUP Sanglah Kota Denpasar. Penelitian observasional ini dilakukan di RSUP Sanglah, Denpasar pada periode Maret 2016 sampai Juni 2016. Kriteria subyek penelitian adalah pasien anak dengan penyakit autoimun pada usia 0-18 tahun yang menjalani rawat inap, rawat jalan dan rawat darurat di RSUP Sanglah, Denpasar. Data pasien diperoleh dari rekam medis serta buku registrasi dan sensus semua pasien anak pada periode Januari tahun 2015 sampai Juni 2016. Angka kejadian penyakit autoimun pada anak disajikan secara deskriptif. Pada penelitian ini, terdapat 50 pasien anak dengan penyakit autoimun yang melakukan kontrol pada periode Januari 2015 sampai dengan Juni 2016 yang diperoleh dari 22.881 jumlah anak yang melakukan kunjungan rawat jalan, rawat inap maupun gawat darurat pada periode tahun tersebut. Kesimpulan dari penelitian ini adalah terdapat angka kejadian penyakit autoimun pada periode Januari 2015 sampai Juni 2016 sebesar 0,22\% pada anak di RSUP Sanglah Denpasar (Diantin, et. al., 2016).

Oleh karena itu, dukungan dari anggota keluarga menjadi sangat penting untuk penderita autoimun. Keluarga adalah unit terkecil dari masyarakat yang terdiri atas kepala keluarga dan beberapa orang yang terkumpul dan tinggal di suatu tempat di bawah suatu atap dalam keadaan saling ketergantungan. Menurut Salvicion dan Celis (1998) di dalam keluarga terdapat dua atau lebih dari dua pribadi yang tergabung karena hubungan darah, hubungan perkawinan atau pengangkatan, dihidupnya dalam satu rumah tangga, berinteraksi satu sama lain dan di dalam perannya masing-masing dan menciptakan serta mempertahankan suatu kebudayaan. Baron (2003) mengatakan, keluarga juga diartikan secara lebih luas oleh para sosiolog modern sebagai sistem interaksi relasional yang teratur dan terjadi secara alami, yang biasanya menempati hunian yang sama dalam jangka waktu yang lama, dan memiliki kumpulan 
gambaran antarpribadi yang tersusun melalui pertukaran pesan dari waktu ke waktu. Beebe (1996) mendefinisikan keluarga, yakni keluarga sebagai unit yang terbentuk dari beberapa individu yang menetapi hubungan dengan individu lainnya dalam jangka waktu yang lama di tempat tinggal yang sama, yang biasanya meski tidak selalu disatukan oleh pernikahan atau kekerabatan.

Dalam interaksi keluarga pastinya ada suatu komunikasi. Komunikasi dalam keluarga merupakan hal yang utama dan harus dibina, sehingga para anggotanya merasakan ikatan yang dalam serta saling membutuhkan. Menurut Rae Sedwig (1985) komunikasi keluarga adalah suatu pengorganisasian yang menggunakan kata-kata, sikap tubuh (gesture), intonasi suara, tindakan untuk menciptakan harapan image, ungkapan perasaan serta saling membagi pengertian (Achdiat, 1997). Berdasarkan pernyataan di atas bahwa kata-kata, sikap tubuh, intonasi suara dan tindakan, mengandung maksud tertentu yaitu untuk mengajarkan, mempengaruhi dan memberikan pengertian. Sedangkan tujuan pokok dari komunikasi ini adalah memprakarsai dan memelihara interaksi antara satu anggota dengan anggota lainnya sehingga tercipta komunikasi yang efektif.

Komunikasi dalam keluarga juga dapat diartikan sebagai kesiapan untuk membicarakan dengan terbuka setiap masalah dalam keluarga, baik yang menyenangkan maupun yang menyedihkan, hal ini para anggota akan siap menyelesaikan masalah-masalah yang dihadapi dengan saling membicarakan satu sama lain dengan kesabaran, kejujuran dan keterbukaan (Friendly, 2002) Komunikasi yang terjadi antara lain komunikasi antarpribadi antar anggota keluarga.

Menurut Devito (1989), komunikasi antarpribadi adalah penyampaian pesan oleh satu orang dan penerimaan pesan oleh orang lain atau sekelompok kecil orang, dengan berbagai dampaknya dan dengan peluang untuk memberikan umpan balik segera (Effendy, 2003). Komunikasi antarpribadi merupakan komunikasi antara orang-orang secara tatap muka, yang memungkinkan setiap pesertanya menangkap reaksi orang lain secara langsung, baik secara verbal atau nonverbal. Komunikasi antarpribadi ini adalah komunikasi yang hanya dua orang, seperti suami istri, dua sejawat, dua sahabat dekat, guru-murid, ibu-anak dan sebagainya (Mulyana, 2000) tujuan komunikasi antarpribadi adalah action oriented, yaitu suatu tindakan yang berorientasi pada tujuan tertentu.

Dengan melihat latar belakang di atas, maka fokus dalam penelitian ini adalah untuk menguraikan bagaimana "Komunikasi Antarpribadi di antara Anggota Keluarga dalam Mendukung Penderita Autoimun". Masalah Penelitian: Bagaimana Komunikasi antarpribradi antar anggota keluarga dalam memotivasi kesembuhan penderita Autoimun (ODAMUN)? Tujuan dari penelitan adalah untuk mengetahui komunikasi antar anggota keluarga dalam memotivasi kesembuhan penderita autoimun secara efektif, untuk mengetahui keluhan penderita Autoimun yang disampaikan penderita autoimun, dan untuk mengetahui solusi penderita dan anggota keluarga dalam menghadapi penderita autoimun. 
Pengertian komunikasi antarpribadi adalah komunikasi yang berlangsung dalam situasi tatap muka antara dua orang atau lebih, baik secara terorganisasi maupun pada kerumunan orang (Wiryanto, 2004). Menurut Devito (1989), komunikasi antarpribadi adalah penyampaian pesan oleh satu orang dan penerimaan pesan oleh orang lain atau sekelompok kecil orang, dengan berbagai dampaknya dan dengan peluang untuk memberikan umpan balik dengan segera (Effendy, 2003). Komunikasi antarpribadi adalah komunikasi antara orang-orang secara tatap muka, yang memungkinkan setiap pesertanya menangkap reaksi orang lain secara langsung, baik secara verbal atau nonverbal. Komunikasi antarpribadi ini adalah komunikasi yang dilakukan oleh dua orang, seperti suami istri, dua sejawat, dua sahabat dekat, guru-murid, ibuanak dan sebagainya (Mulyana, 2000).

Miller (1978) mendefinisikan komunikasi antarpribadi diartikan sebagai komunikasi dengan sejumlah partisipan atas dasar tertentu. Ketika dua orang sedang menjalin hubungan yang intim maka akan terjadi komunikasi antarpribadi antar orang sehingga dapat memberikan umpan balik langsung dengan berbagai cara (Liliweri, 2015). Komunikasi antarpribadi tidak hanya sekedar pertukaran informasi antara dua orang atau lebih. Namun pengertian komunikasi antarpribadi sendiri lebih banyak tentang bagaimana manusia menciptakan, bernegosiasi, mengidentifikasi, menjelaskan dan berhubungan melalui interaksi sosial dengan berkomunikasi secara antarpribadi. Bagaimana manusia membentuk diri mereka sendiri dan hubungannya dengan orang-orang di sekitar mereka (Craig, Baxter, Braithwaite \& Schordt 2014). Menurut Johnson (1981), komunikasi antar manusia memiliki peran ganda dalam menciptakan kebahagiaan dalam kehidupan manusia (Morrisan, 2013). Maka pengertian komunikasi antarpribadi bisa disimpulkan setelah memahami dari pengertian-pengertian para ahli, maka komunikasi antarpribadi adalah komunikasi yang dilakukan oleh manusia yang dilakukan oleh dua orang atau lebih dengan menggunakan bentuk komunikasi verbal maupun nonverbal yang dapat menentukan dan menciptakan hubungan serta perilaku manusia serta mendapatkan umpan balik.

Ciri-ciri komunikasi antarpribadi yang paling menonjol adalah efek perubahan sikap. Hal ini terjadi diantaranya adalah komunikasi antarpribadi dilakukan secara tatap muka, berada dalam jarak dekat (Ngalimun, 2018). Komunikasi antarpribadi adalah proses komunikasi yang sering terjadi di dalam kehidupan sehari-hari. Terdapat lima ciri-ciri dari komunikasi inter personal menurut Aw (2011), yaitu arus pesan dua arah, arus ini berlangsung secara berkelanjutan atau secara intens antara komunikator dengan komunikan. Komunikator dan komunikan berada dalam posisi yang sama sehingga dapat berganti peran secara tepat, dengan maksud, seorang komunikator (pengirim pesan) bisa berubah menjadi seorang komunikan (penerima pesan) dan sebaliknya. Suasana nonformal, pendekatan individu bersifat pertemanan merupakan komunikasi antarpribadi yang sering berlangsung baik secara verbal maupun nonverbal. Dengan arti, komunikasi antarpribadi juga bisa berlangsung dalam situasi nonformal, seperti orang tua dengan anak. Umpan balik segera, komunikasi antarpribadi merupakan proses komunikasi yang bisa terjadi secara langsung atau tatap muka sehingga komunikator (pengirim pesan) dapat dengan cepat memperoleh feedback atau mengembalikan pesan yang ingin disampaikan kepada komunikan (penerima pesan). 
Peserta komunikasi berada dalam jarak yang dekat, proses komunikasi antarpribadi yang terjadi antara individu dengan individu yang lain berada dalam jarak dekat secara fisik atau psikologis sehingga menunjukkan keintiman hubungan antara komunikator (pengirim pesan) dengan komunikannya (penerima pesan). Peserta komunikasi menerima pesan secara stimulus dan spontan, baik verbal maupun nonverbal. Peserta komunikasi dapat menggunakan kekuatan pesan secara verbal dan nonverbal pada saat yang bersamaan untuk meningkatkan efisiensi komunikasi antarpribadi. Misalnya dengan mengoptimalkan pesan nonverbal yang mendukung pesan verbal.

Tujuan Komunikasi Antarpribadi adalah Komunikasi antarpribadi merupakan action oriented, ialah suatu tindakan yang berorientasi pada tujuan tertentu, beberapa di antaranya: (1) mengungkapkan perhatian kepada orang lain, (2) menemukan diri sendiri, (3) menemukan dunia luar, (4) membangun dan memelihara hubungan yang harmonis, (5) mempengaruhi sikap dan tingkah laku, (6) mencari kesenangan atau sekedar menghabiskan waktu, (7) menghilangkan kerugian akibat salah komunikasi, dan (8) memberikan bantuan (konseling) (Aw, 2011).

Menurut Ngalimun (2018) Proses komunikasi antarpribadi menggambarkan langkah-langkah dari kegiatan komunikasi. Proses komunikasi antarpribadi yang efektif jika terdapat proses yang menghubungkan suatu pengiriman dan penerimaan sebuah pesan.

\section{Gambar 2. Proses Komunikasi antarpribadi}

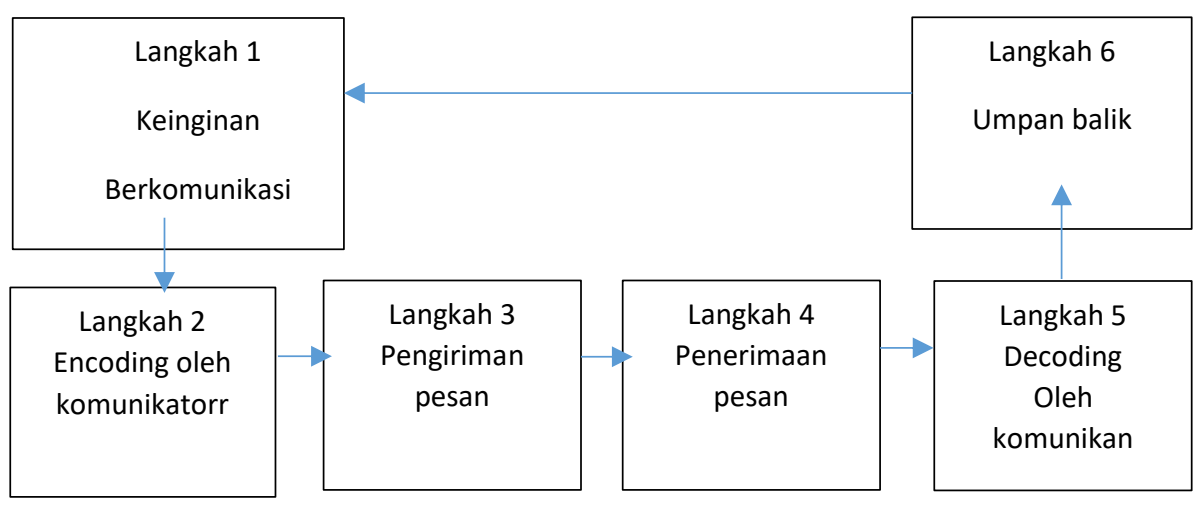

Sumber: Ngalimun (2018)

Terdapat enam langkah dalam proses komunikasi antarpribadi, yaitu (1) keinginan berkomunikasi, seorang pengirim pesan atau komunikator ingin berbagi sebuah gagasan bersama orang lain. (2) Encoding oleh komunikator, encoding adalah tindakan untuk memformulasikan pesan ataupun gagasan seseorang kedalam sebuah komunikasi verbal maupun nonverbal berupa simbol atau perkataan dengan tujuan komunikator merasa percaya diri terkait pesan yang telah disusun dan penyampaian pesan. (3) Pengiriman pesan, seorang pengirim pesan memilih saluran komunikasi dengan cara SMS, e-mail, tatap muka, video call 
untuk mengirim pesan kepada seseorang. Cara pengiriman pesan tersebut bergantung kepada lokasi komunikan, media yang dimiliki, karakteristik komunikan, kebutuhan akan usatu pesan yang ingin disampaikan. (4) Penerimaan pesan, komunikan telah menerima pesan yang sebelumnya telah dikirim oleh komunikator. (5) Decoding oleh komunikan, decoding adalah suatu kegiatan yang ada dalam diri komunikan. Komunikan mendapatkan berbagai data dalam bentuk yang mentah melalui indra, data tersebut berupa simbol. Kata-kata yang perlu diubah kedalam sesuatu yang mengandung arti. (6) Umpan balik, komunikan akan memahami pesan yang diterima dan memberikan respon sehingga komunikator dapat mengevaluasi efektivitas dari komunikasi yang telah dilakukan supaya proses komunikasi dapat berlanjut.

Menurut DeVito (2013), mengatakan bahwa prinsip-prinsip komunikasi antarpribadi adalah sebagai berikut komunikasi antarpribadi adalah suatu proses transaksional. Komunikasi antarpribadi adalah sebuah proses, atau kejadian yang berkelanjutan, dimana masing-masing elemen saling bergantung satu sama lain. Komunikasi antarpribadi secara konstan terus terjadi dan mengalami perubahan. Agar dapat memahami gambaran komunikasi antarpribadi sebagai proses transaksional maka model komunikasi transaksional dapat menjadi jawabannya. Komunikasi antarpribadi memiliki lima tujuan yang dikemukakan oleh De Vito, yaitu (1) untuk belajar - komunikasi antarpribadi membuat kita dapat belajar memahami orang lain dan dunia secara lebih baik. (2) Untuk membina hubungan - komunikasi antarpribadi membantu kita untuk berhubungan dengan orang lain. (3) Untuk mempengaruhi - melalui komunikasi antarpribadi kita dapat mempengaruhi sikap dan perilaku orang lain. (4) Untuk bermain komunikasi antarpribadi dapat berfungsi sebagai kegiatan bermain. (5) Untuk membantu melalui komunikasi antarpribadi seorang terapis menggunakan teknik penyebuhan jiwa yang dikenal dengan metode komunikasi terapeutik dalam keperawatan.

Komunikasi antarpribadi adalah ambigu. Semua pesan-pesan berpotensi ambigu, masingmasing orang akan memberikan makna yang berbeda terhadap pesan yang sama. Terdapat ambiguitas dalam semua hubungan. Hubungan antarpribadi dapat berbentuk simetris atau komplementer. Interaksi yang dapat digunakan dalam komunikasi antarpribadi ini dapat merangsang pola perilaku yang sama atau berbeda. Komunikasi antarpribadi merujuk pada isi dan hubungan diantara para partisipan. Dalam sistem komunikasi antarpribadi, hubungan antarpribadi memegang peranan yang sangat penting karena hubungan antarpribadi yang baik merupakan penanda bagi komunikasi yang efektif. Komunikasi antarpribadi adalah dapat diberi tanda atau ditandai. karenanya setiap orang memisahkan bagian-bagian komunikasi ke dalam stimuli atau rangsangan dan respon terhadap perspektif dasar yang dimiliki oleh masingmasing partisipan. Komunikasi antarpribadi tidak dapat dihindari, tidak dapat diulang, dan tidak dapat diubah. Ketika berada dalam sebuah situasi antarpribadi, kita tidak dapat tidak berkomunikasi, dan kita tidak dapat mengulang secara tepat sebuah pesan secara spesifik.

Taylor (1997) mengatakan bahwa komunikasi antarpribadi yang efektif mempunyai banyak unsur, namun hubungan antarpribadi adalah yang paling penting (Rakhmat, 2018). Menurut Ngalimun (2018) komunikasi antarpribadi dikatakan efektif jika mempunyai tiga persyaratan dibawah ini (1) pesan dapat diterima dan dimengerti oleh penerima pesan sebagaimana yang 
telah disampaikan oleh pengirim pesan pada jalannya komunikasi, (2) pesan yang disampaikan oleh komunikator dilanjutkan oleh komunikan secara sukarela, (3) komunikasi antarpribadi yang dilakukan dapat membuat kualitas hubungan antarpribadi semakin meningkat, intim, dan erat.

Ciri-ciri dari komunikasi antarpribadi yang efektif mengutip pendapat DeVito (2013) sebagai berikut: keterbukaan (openness), kemauan menanggapi dengan senang hati informasi yang diterima di dalam menghadapi hubungan antarpribadi. Kualitas keterbukaan mengacu pada tiga aspek dari komunikasi antarpribadi. Pertama, komunikator antarpribadi yang efektif harus terbuka kepada komunikannya. Ini tidaklah berarti bahwa orang harus dengan segera membukakan semua riwayat hidupnya. Memang ini mungkin menarik, tetapi biasanya tidak membantu komunikasi. Sebaliknya, harus ada kesediaan untuk membuka diri mengungkapkan informasi yang biasanya disembunyikan, asalkan pengungkapan diri ini patut dan wajar.

Aspek kedua mengacu pada kesediaan komunikator untuk bereaksi secara jujur terhadap stimulus yang datang. Orang yang diam, tidak kritis, dan tidak tanggap pada umumnya merupakan komunikan yang menjemukan. Bila ingin komunikan bereaksi terhadap apa yang komunikator ucapkan, komunikator dapat memperlihatkan keterbukaan dengan cara bereaksi secara spontan terhadap orang lain. Aspek ketiga menyangkut kepemilikan perasaan dan pikiran dimana komunikator mengakui bahwa perasaan dan pikiran yang diungkapkannya adalah miliknya dan ia bertanggung jawab atasnya. Empati (empathy) Empati adalah kemampuan seseorang untuk mengetahui apa yang sedang dialami orang lain pada suatu saat tertentu, dari sudut pandang orang lain itu, melalui kacamata orang lain itu. Berbeda dengan simpati yang artinya adalah merasakan bagi orang lain. Orang yang berempati mampu memahami motivasi dan pengalaman orang lain, perasaan dan sikap mereka, serta harapan dan keinginan mereka untuk masa mendatang sehingga dapat mengkomunikasikan empati, baik secara verbal maupun non-verbal. Dukungan (supportiveness) Situasi yang terbuka untuk mendukung komunikasi berlangsung efektif. Hubungan antarpribadi yang efektif adalah hubungan dimana terdapat sikap mendukung. Individu memperlihatkan sikap mendukung dengan bersikap deskriptif bukan evaluatif, spontan bukan strategik. Rasa Positif (positiveness) Seseorang harus memiliki perasaan positif terhadap dirinya, mendorong orang lain lebih aktif berpartisipasi, dan menciptakan situasi komunikasi kondusif untuk interaksi yang efektif. Kesetaraan (equality) Komunikasi antarpribadi akan lebih efektif bila suasananya setara. Artinya, ada pengakuan secara diam-diam bahwa kedua belah pihak menghargai, berguna, dan mempunyai sesuatu yang penting untuk disumbangkan. Kesetaraan meminta kita untuk memberikan penghargaan positif tak bersyarat kepada individu lain (Liliweri, 1991).

Kata motivasi (motivation) kata aslinya adalah motif (motive) yang berarti dorongan, hal ini membuat individu terdorong untuk melakukan sesuatu. Dengan demikian motivasi berarti suatu keadaan dan situasi yang mendorong individu melakukan suatu kegiatan, yang berlangsung secara sadar (Sumantri, 2012). Motivasi adalah serangkaian energi yang berasal baik dari dalam maupun dari luar individu, untuk memulai kegiatan yang berhubungan dengan perilaku dan menentukan bentuk, arah, intensitas, dan durasi kegiatan (Pinder, 1998). Dengan 
demikian, motivasi adalah proses psikologis yang dihasilkan dari interaksi antara individu dan lingkungan. Kanfer (1992) menyatakan bahwa motivasi adalah dorongan kekuatan untuk mendapatkan dan membuat sesuatu terjadi. Jadi jelaslah bahwa motivasi berkaitan dengan faktor-faktor yang mendorong atau menarik individu untuk berperilaku dengan cara tertentu.

Pendapat lain yang disampaikan oleh Locke dan Latham (1990) bahwa motivasi adalah variasi dalam kegiatan individu yang bukan karena kemampuan atau situasi, tetapi beberapa individu melakukan kegiatan lebih baik daripada individu lain karena memiliki tujuan yang berbeda (Locke \& Latham, 1990). Sejalan dengan pendapat Locke dan Latham (1990) mengacu pada teori sosial kognitif, motivasi bukan tujuan itu sendiri melainkan perbedaan yang diciptakan oleh individu dalam membandingkan bagaimana mereka melakukan yang bisa memotivasi perilaku (Bandura, 1986). Hasil evaluasi ini disampaikan oleh Wright (2004) yaitu rasa persetujuan diri atau ketidakpuasan diri yang berfungsi untuk memotivasi individu dalam bertindak dengan cara yang menghasilkan evaluasi diri positif atau mengurangi evaluasi diri negatif. Dengan demikian apa yang disampaikan Bandura, Locke dan Latham serta Wright, bahwa motivasi bukan merupakan situasi lingkungan namun merupakan dorongan diri dalam mencapai suatu tujuannya. Hal ini sesuai dengan pandangan bahwa motivasi merupakan suatu proses dimana kebutuhan yang mendorong individu untuk melakukan serangkaian kegiatan yang mengarah pada ketercapaian tujuan tertentu (Mangkunegara, 2009).

Sependapat dengan yang lain motivasi, menurut Greenberg dalam Djaali (2008) adalah proses membangkitkan, mengarahkan, dan memantapkan perilaku arah suatu tujuan. Selain itu Sumardi dalam Djaali (2008) mengatakan bahwa motivasi adalah keadaan yang terdapat dalam diri seseorang yang mendorongnya untuk melakukan kegiatan guna mencapai suatu tujuan. Motivasi adalah proses psikologis yang dapat menjelaskan perilaku seseorang. Perilaku hakikatnya merupakan orientasi pada suatu tujuan. Untuk mencapai tujuan tersebut diperlukan proses interaksi dari unsur. Dengan demikian, motivasi merupakan kekuatan yang mendorong seseorang melakukan sesuatu untuk tujuan tertentu. Kekuaatan-kekuatan ini pada dasarnya dirangsang oleh berbagai macam kebutuhan, seperti keinginan yang hendak dipenuhinya, tingkah laku, dan umpan balik (Uno, 2008). Sumber motivasi seseorang untuk mencapai tujuannya terbagi dua menurut (Widodo, 2005) sumber motivasi internal, orang yang cenderung memiliki sumber motivasi internal, termasuk untuk memutuskan berdasarkan standar di dalam dirinya, mereka kesulitan menerima opini atau perintah dari luar. Pada dasarnya mereka mengumpulkan informasi dari luar, tetapi kemudian memutuskan dengan standar internalnya. Sumber motivasi eksternal, orang yang cenderung memiliki sumber motivasi eksternal, termotivasi bila ada tanggapan dari orang lain. Mereka memerlukan opini, arahan dari luar atau tanggapan dari pihak lain untuk tetap termotivasi eksternal tidak memiliki standar di dalam dirinya, mereka mendapatkan dari luar.

\section{METODE PENELITIAN}

Penelitian ini menggunakan metode penelitian kualitatif. Moleong (2010) menjelaskan penelitian kualitatif adalah data yang dikumpulkan dengan menggunakan metode alami di 
lingkungan alam, yang dilakukan oleh orang yang berkepentingan atau peneliti. Menurut Sugiyono (2015), metode penelitian pada dasarnya adalah metode ilmiah untuk memperoleh data untuk tujuan dan kegunaan tertentu. Berdasarkan hal tersebut, empat kata kunci yang perlu diperhatikan yaitu metode ilmiah, data, maksud dan tujuan. Pendekatan ilmiah berarti bahwa kegiatan penelitian dilandasi oleh sifat-sifat keilmuan yaitu rasionalitas, pengalaman dan sistemik. Nalar artinya kegiatan penelitian dilakukan dengan cara yang bermakna sehingga nalar manusia dapat menjangkau mereka. Pengalaman berarti metode yang lengkap dapat diamati melalui persepsi manusia sehingga orang lain dapat mengamati dan memahami metode yang digunakan. Sistematis artinya proses yang digunakan dalam penelitian menggunakan langkah-langkah logis tertentu.

Fenomenologi bisa dikatakan ilmu tentang fenomena yang muncul dari kesadaran para peneliti. Secara garis besar, fenomenologi adalah ilmu tentang gejala atau hal-hal yang muncul (Yusuf, 2014). Penelitian fenomenologi berusaha menjelaskan atau mengungkap makna konsep atau fenomena empiris berdasarkan kesadaran yang muncul pada banyak individu. Penelitian ini dilakukan dalam kondisi alamiah, sehingga tidak ada batasan dalam menjelaskan atau memahami fenomena yang diteliti (Agustinova, 2015). Menurut Creswell (1998), metode fenomenologi menunda semua penilaian tentang sikap alami sampai dasar tertentu ditemukan. Penundaan ini sering disebut sebagai epoche. Konsep epoche adalah untuk membedakan antara area data dan interpretasi peneliti. Konsep Epoche berada di pusat kompilasi dan klasifikasi peneliti dari hipotesis awal tentang fenomena untuk memahami apa yang dikatakan oleh narasumber. Melalui wawancara mendalam, peneliti fenomenologi mencoba memahami orang melalui perspektif mereka (Agustinova, 2015).

Nurhadi (2015) menyimpulkan bahwa dasar fenomenologis mempunyai tiga prinsip, diantaranya (1) melalui pengalaman yang sadar pengetahuan ditemukan secara langsung, (2) seseorang akan mengetahui apa itu dunia ketika mempunyai hubungan dengan pengalamannya, dan (3) makna benda mencakup kekuatan benda-benda dalam kehidupan seseorang. Ketika seseorang berhubungan dengan suatu benda maka hal tersebut akan menentukan arti dari benda itu baginya. Bahasa adalah pembawa makna seseorang mengetahui dunia melalui bahasa yang orang itu pakai untuk membuat pengertian dan menunjukan hal apa yang dilakukan di dunia tersebut.

Narasumber merupakan seseorang yang akan memberikan sebuah informasi atas pengalaman yang dialami karena dengan hal itu peneliti akan mengetahui informasi yang berguna. Peneliti akan melakukan wawancara dengan narasumber yang dianggap sesuai dengan penelitian yang akan dijalankan yaitu melakukan wawancara kepada beberapa pihak keluarga yang mempunyai anggota keluarga yang menderita autoimun. Narasumber terdiri dari 4 nara sumber penderita autoimun semua kebetulan perempuan, 3 keluarga dari penderita. Identitas Nara sumber ODAMUN:

1. RN (24 th), diagnosis autoimun sejak SMA yaitu usia 16 th dengan jenis Rematic,Artitis Fibrodiagial

2. WW (48 th); diagnosis autoimun sejak Th. 2006 (34 th) dengan jenis Lupus dengan kasta terendah.

3. MT (33 Th); diagnosis autoimun sejak tahun 2018 dengan jenis Lopus 
4. FR (23 th) diagnosis autoimun sejak Th. 2016) dengan jenis Lopus

Nara sumber keluarga: AT (kakak RN); TN (Suami WW); YY (Ibunya MT); Ibunya FR belum bersedia diwawancara dikarenakan ayahnya FR baru dua minggu meninggal dan FR adalah anak tunggal. Ada beberapa teknik pengumpulan data yang digunakan untuk metode penelitian kualitatif berikut ini adalah teknik pengumpulan data yang digunakan untuk metode kualitatif (Agustinova, 2015) yaitu (1) dokumen adalah suatu teknologi pengumpulan data dengan berbagai buku, dokumen dan karya yang terkait, digunakan untuk menyusun konsep penelitian dan mengungkap objek penelitian. Teknik ini digunakan untuk menggali berbagai data faktual terkait masalah yang menjadi objek penelitian. (2) Wawancara, menurut Yusuf (2014) Wawancara terencana-tidak terstruktur

Wawancara terencana-tidak terstruktur mengacu pada situasi di mana peneliti atau pewawancara menyiapkan rencana wawancara yang terstruktur, tetapi tidak menggunakan format dan urutan baku. Alasan peneliti menggunakan wawancara teknik pengumpulan data berupa wawancara dengan tipe wawancara terencana-tidak terstruktur karena peneliti ingin menemukan banyak faktor penyebab atas topik yang dibahas.

Menurut Sugiyono (2011), teknik analisis data merupakan proses dalam mencari dan menyusun secara sistematis data yang diperoleh dari hasil wawancara, catatan lapangan, dan dokumentasi, dengan cara mengorganisasikan data ke dalam kategori, lalu menjabarkan ke dalam unit unit, melakukan Sintesa, menyusun ke dalam pola, memilih yang mana yang penting yang akan dipelajari, dan membuat kesimpulan sehingga mudah dipahami oleh diri sendiri maupun oleh orang lain. Dalam penelitian ini peneliti menggunakan tahap yang terjadi ketika melakukan analisis data oleh Miles dan Huberman (Sugiyono, 2011). Reduksi data merupakan proses untuk mencari, menyederhanakan, merangkum, memilih, mengubah hal hal yang penting untuk peneliti. Semua hal itu merupakan hal yang objektif dengan hasil observasi dan wawancara di lapangan dengan catatan data dengan berbagai bentuk data yang ada di lapangan. Mereduksi sebuah data berarti merangkum, memilih hal hal yang pokok, memfokuskan pada hal hal yang penting, dicari tema dan polanya dan membuang hal yang tidak perlu. Dengan demikian data yang telah direduksi akan memberikan gambaran yang lebih jelas, dan mempermudah peneliti untuk melakukan pengumpulan data selanjutnya dan mencarinya bila diperlukan (Sugiyono, 2010). Tahap conclusion ini, peneliti membuat kesimpulan sementara dari penelitian yang sedang di olah atau dikerjakan. Dikatakan kesimpulan sementara karena kesimpulan akhir hanya akan didapat setelah pengumpulan semua data dan benar benar selesai.

Menurut Moleong (2010) mengemukakan bahwa kriteria dari keabsahan suatu data terdapat empat macam (1) kepercayaan (credibility), seorang peneliti dianggap kredibel jika penelitian tersebut dihasilkan dari sumber yang terpercaya. (2) Keteralihan (transferability), peneliti memiliki peranan untuk membantu pembaca dalam mentransfer pengetahuan spesifik yang diperoleh dari penelitian ke situasi yang mereka kenal. (3) Kebergantungan (dependability), suatu penelitian harus dilakukan dengan stabil dan konsisten agar mencapai hasil yang akurat dan dapat menjadi sumber untuk penelitian selanjutnya. (4) Kepastian (confirmability), hasil penelitian yang didapatkan bukan hanya asumsi dari peneliti tetapi hasil penelitian tersebut 
didapatkan langsung dari sumber yang terpercaya sehingga pembaca dapat menyimpulkan bahwa hasil penelitian memang didapat langsung dari sumber yang terpercaya.

Dalam uji kredibilitas penelitian ini menggunakan teknik triangulasi sumber data. Triangulasi sumber data adalah menguji kredibilitas data dengan memeriksa data yang telah diperoleh melalui berbagai sumber. Data dari berbagai sumber tersebut tidak dapat disama-ratakan seperti halnya penelitian kuantitatif, data tersebut akan diuraikan kemudian, diklasifikasikan, dilihat mana yang sama, pandangan mana yang berbeda, dan mana yang spesifik dari sumber tersebut. Setelah mencapai kesimpulan, diperlukan kesepakatan dengan sumber data. (Agustinova, 2015).

Tabel 1. Tahap Pengumpulan Data

\begin{tabular}{|c|c|c|c|}
\hline $\begin{array}{l}\text { Obyek } \\
\text { Penelitian }\end{array}$ & Elemen & Evidensi & $\begin{array}{l}\text { Pengambilan } \\
\text { Data }\end{array}$ \\
\hline \multirow{5}{*}{$\begin{array}{l}\text { Komunikasi } \\
\text { Antar- } \\
\text { pribadi } \\
\text { antara } \\
\text { anggota } \\
\text { keluarga } \\
\text { secara } \\
\text { efektif dari } \\
\text { Joseph } \\
\text { A.Devito } \\
\text { (Allo } \\
\text { Liliweri, } \\
\text { 2013) }\end{array}$} & Keterbukaan & $\begin{array}{l}\text { 1)Mengungkapkan diri secara patut dan wajar } \\
\text { 2)Bereaksi secara spontan dan jujur } \\
\text { 3)Bertanggung jawab atas perasaan dan pikiran }\end{array}$ & \multirow[t]{5}{*}{ Wawancara } \\
\hline & Empati & $\begin{array}{l}\text { mampu memahami motivasi dan pengalaman } \\
\text { orang lain, perasaan dan sikap mereka }\end{array}$ & \\
\hline & Dukungan & $\begin{array}{l}\text { sikap mendukung dengan bersikap deskriptif } \\
\text { bukan evaluatif, spontan bukan strategik. }\end{array}$ & \\
\hline & Rasa Positif & $\begin{array}{l}\text { menciptakan situasi komunikasi kondusif } \\
\text { untuk interaksi yang efektif. }\end{array}$ & \\
\hline & Kesetaraan & $\begin{array}{l}\text { kedua belah pihak menghargai, berguna, dan } \\
\text { mempunyai sesuatu yang penting untuk } \\
\text { disumbangkan. }\end{array}$ & \\
\hline
\end{tabular}

Sumber: Olahan Peneliti

\section{HASIL DAN PEMBAHASAN}

\section{Komunikasi antar anggota keluarga dalam memotivasi kesembuhan}

Keterbukaan: RN dan XX: RN mengungkapkan sakitnya dan cerita pada keluarga dan ingin ditemani, keluarga merasa sedih, kenapa tidak sembuh-sembuh, kakak lebih mencari solusi membawa ke UGD. Ke empat narasumber ODAMUN menceritakan tentang diagnosis dari dokter tentang penyakit Autoimun, tujuan menceritakan supaya tidak merasa kuatir dengan keadaan tersebut, selain itu tidak menganggap Odamun malas dalam bekerja.

Mengungkapkan diri secara patut dan wajar, jadi para naras sumber ODAMUN dengan mencertakan secara wajar dan pantas membuat keluarganya menjadikan lebih mampu memberikan motivasi yang diharapkan oleh penderita. Hal ini sesuai dengan disampaikan oleh 
YY ibu dari MT sebagai anggota keluarga merasa bertanggung jawab atas perasaan dan pikiran yang disampaikan oleh penderita. Jadi keterbukaan ini adalah kunci utama untuk menuju kesembuhan (Alimuary, 2020).

Empati: Empati dari keluarga lebih kearah menemani dan mencari informasi ke dokter, beda dengan naras sumber MT keluarganya (Ibunya) lebih kearah mendoakan dan menerima keadaan MT. Kakak RN lebih empati dengan cara mencari solusi. Keluarga memahami keadaan RN dan tiduran disebelahnya, dan pegang tangannya. Kalau diajak bicara agak kesal, maka keluarga lebih baik diam dan mengamati keinginan penderita.

Dukungan: Dukungan dari keluarga sangat berarti bagi ODAMUN. Odamun ingin didampingi, dibiarkan diam untuk menikmati sakitnya itulah yang menjadi keinginan Odamun. Hal ini dikatakan oleh Odamun WW lebih baik didiamkan dulu kalau sudah tidak kuat WW akan mengatakan pada suaminya. Situasi yang terbuka untuk mendukung komunikasi berlangsung efektif. Hubungan antarpribadi yang efektif adalah hubungan dimana terdapat sikap mendukung. Dari keempat ODAMUN, yang melakukan pengobatan herbal adalah FR dan WW ini karena bertujuan untuk mengurangi konsumsi obat.

Rasa Positif: berserah kepada Tuhan dan membandingkan teman-teman yang autoimun yang lebih berat, dan saling mendukung sesama anggota. Mengelola stress dan berpikir positif. Hal ini dilakukan oleh ODAMUN RN, WW dan FR, sedang MT lebih kritis dan lebih pembenaran diri, "MT lebih mengatakan ini adalah sakit, yang penting ke dokter dan menghindari penyebab kambuhnya sakit tersebut.

Kesetaraan: Ketika keluarga memberikan masukan RN menerimanya demi kebaikan. Mencari informasi ke dokter. dan Kesetaraan dalam komunikasi tidak ada yang merasa dominan karena RN selalu didenganr pendapatnya. Dan kakak beradik ini bisa memberikan masukan dengan terbuka. FR lebih bisa cerita pada ibunya dan ibunya lebih mendengarkan dan melayani keperluan FR. Sedang keluarga MT, lebih berdiskusi dan mencari tahu dari internet dan buku.

Dari kelima faktor komunikasi antarpribadi yang paling menonjol dari keluarga adalah dukungan, karena dengan dukungan keluarga para Odamun merasa nyaman dan merasa ditemani dalam sakitnya, inilah salah satu motivasi untuk kesembuhan sepertinya diuraikan oleh Pinder dan Kanfer tentang motivasi merupakan serangkaian energi yang berasal baik dari dalam maupun dari luar individu, untuk memulai kegiatan yang berhubungan dengan perilaku dan menentukan bentuk, arah, intensitas, dan durasi kegiatan (Pinder, 1998). Dengan demikian, motivasi adalah proses psikologis yang dihasilkan dari interaksi antara individu dan lingkungan. Kanfer (1992) menyatakan bahwa motivasi adalah dorongan kekuatan untuk mendapatkan dan membuat sesuatu terjadi yaitu kesembuhan.

\section{Penyampaian keluhan penderita autoimun}

Menurut: RN, Habis kena panas kaki, jari terasa nyeri dan sakit telapak kakinya, kulit mengelupas, rambut rontok, muka kepanasan merah seperti bentuk kupu-kupu . Ada keluarga/ 
sepupunya yang juga menderita Lupus. Pada kulit ada bintik merah seperti Timbul dipermukaan kulit dan merah. Dari pandangan orang lain dianggapnya manja atau malas kerja, padahal sedang merasakan sakit, dan kalau dipegang semakin sakit. WW, MT rambutnya rontoh dan mukanya merah-merah seolah-olah kebakar, FR sakit seluruh tubuhnya dan panas sebagian tubuhnya, sariawan. Tanda-tanda ini juga tergantung dari masing-masing individu. Yang paling menonjol dari ke empat naras sumber mengatakan tanda-tandanya adalah lemas tak bertenaga, kulit merah panas, dan terjadi sariwan. Pencetus utama penyakit ini muncul adalah banyak pikiran yang mengakibatkan stress.

Solusi anggota keluarga dalam menanggapi keluhan penderita. Solusi Dari RN, minum obat teratur dan tidak stress, dan mendapat dukungan dari keluarga. Biasanya Mama dan papanya pada bingung dan nangis ketika melihat keadaan RN sakit. AT adalah kakak RN, memberikan ketenangan dan memegang tangan $\mathrm{RN}$. Menurut TN suami WW, ia lebih tenang dan mencari tahu dari internet dan buku lalu membeli obat untuk WW. Sedangkan YY ibu dari MT, lebih membantu melayani keperluan MT dan berdoa untuk kesembuhan putrinya. Hal ini sesuai dengan penyataan dari Uno (2008) motivasi merupakan kekuatan yang mendorong seseorang melakukan sesuatu untuk tujuan tertentu yaitu kesembuhan penderita. Kekuatan-kekuatan ini pada dasarnya dirangsang oleh berbagai macam kebutuhan, seperti: Keinginan yang hendak dipenuhinya yang hidup normal kembali, dengan tingkah laku yang mengarah pada dukungan keluarga dan dari penderita harus bisa mengelola stress. Jadi umpan balik dari antar anggota menjadi setara dan seimbang untuk mencapai tujuan kesembuahan (Uno, 2008).

Dalam komunikasi antarpribadi secara efektif antara para ODAMUN dengan anggota keluarganya sangat diperlukan, karena ini berkaitan dengan keterbukaan, empati, sikap mendukung, sikap positif dan kesetaraan dalam komunikasi menjadi faktor penentu kesembuhan bagi penderita autoimun. Hal ini sesuai dinyatakan oleh Djaali (2008) motivasi adalah proses membangkitkan, mengarahkan, dan memantapkan perilaku untuk mengarah suatu tujuan yaitu kesembuhan (Prathiwi, 2020).

Selain itu, Sumardi dalam Djaali (2008) mengatakan bahwa motivasi adalah keadaan yang terdapat dalam diri seseorang yang mendorongnya untuk melakukan kegiatan guna mencapai suatu tujuan. Jadi komunikasi antarpribadi dianggap efektif menurut Ngalimun (2018) jika mempunyai tiga persyaratan: (1) pesan dapat diterima dan dimengerti oleh penerima pesan sebagaimana yang telah disampaikan oleh pengirim pesan pada jalannya komunikasi, hal ini Odamun dan keluarganya saling bisa mengerti dan memahami apa yang dikomunikasikan oleh ODAMUN. (2) Pesan yang disampaikan oleh komunikator dilanjutkan oleh komunikan secara sukarela, jelas Odamun membuka diri untuk menyampaikan diagnosa yamg didapat dari dokter yang merawatnya. (3) Komunikasi antarpribadi yang dilakukan dapat membuat kualitas hubungan antarpribadi semakin meningkat, intim, dan erat, jelas para anggota keluarga lebih dekat dan empat dengan para penderita autoimun. Yang mana keakrabannya itu bertujuan untuk memotivasi kesembuhan ODAMUN. 
Terkait dengan komunikasi antarpribadi pada ODAMUN dan anggota keluarganya, prinsip komunikasi antarpribadi yang menonjol adalah: suatu proses transaksional menurut (DeVito, 2013), Komunikasi antarpribadi adalah sebuah proses, atau kejadian yang berkelanjutan, dimana masing-masing elemen saling bergantung satu sama lain. Komunikasi antarpribadi secara konstan terus terjadi dan mengalami perubahan. Agar dapat memahami gambaran komunikasi antarpribadi sebagai proses transaksional maka model komunikasi transaksional dapat menjadi jawabannya bagi ODAMUN dan keluarganya. Selain itu, De Vito (2013) juga mengungkapkan komunikasi antarpribadi memiliki tujuan. Yaitu 5 (lima) tujuan, yaitu: untuk belajar - komunikasi antarpribadi membuat kita dapat belajar memahami orang lain dan dunia secara lebih baik. Sebagaimana dari keluarga ODAMUN belajar dari pengalaman merawat dan mendampingi ODAMUN. Untuk membina hubungan - komunikasi antarpribadi membina hubungan antar anggota keluarga ODAMUN. Untuk mempengaruhi - melalui komunikasi antarpribadi kita dapat mempengaruhi sikap dan perilaku orang lain, Yaitu anggota keluarga Odamun bisa lebih sabar dan dan bersikap memahami ODAMUN. Untuk bermain, hal ini tampak pada saat ODAMUN merasa sehat mereka lebih bicara yang ringan-ringan dengan tujuan supaya tidak merasa stress. Untuk membantu - melalui komunikasi antarpribadi anggota keluarga menggunakan teknik penyebuhan jiwa yang dikenal dengan metode komunikasi terapeutik dalam keperawatan yang dilakukan oleh keluarga akan lebih bermakna untuk motivasi kesembuhan bagi ODAMUN.

Komunikasi antara anggota keluarga terkait dengan Motivasi yang disampaikan oleh Widodo (2005). Sumber motivasi internal para ODAMUN, memiliki keinginan untuk sembuh dengan segala upayanya yaitu mencari tahu bagaimana menghindari pencentus terjadinya kekambuhan melalui diskusi dengan dokter, mencari informasi dari artikel maupun nasehat dari orang lain. Namun informasi tersebut tetap diputuskan oleh dirinya sendiri, mana yang cocok pada dirinya. Hal ini, sesuai pada pernyataan Widodo yaitu orang yang cenderung memiliki sumber motivasi internal, termasuk untuk memutuskan berdasarkan standar di dalam dirinya, mereka kesulitan menerima opini atau perintah dari luar. Pada dasarnya mereka mengumpulkan informasi dari luar, tetapi kemudian memutuskan dengan standar internalnya.

Sumber motivasi eksternal, dalam hal ini para ODAMUN mau menerima masukan dari keluarganya maupun dokter, ketika dirasakan itu merupakan dukungan untuk kesembuhan mereka. Para Odamun bisanya ketika keadaan dirinya tidak berdaya saat menghadapi kekambuhan, maka motivasi eksternal menjadi pilihannya. Sesuai yang disampaikan Widodo (2005), orang yang cenderung memiliki sumber motivasi eksternal, termotivasi bila ada tanggapan dari orang lain. Mereka memerlukan opini, arahan dari luar atau tanggapan dari pihak lain untuk tetap termotivasi eksternal tidak memiliki standar di dalam dirinya, mereka mendapatkan dari luar.

\section{SIMPULAN}

Dalam Komunikasi antarpribadi antar anggota keluarga dalam menghadapi penderita autoimun dari empat subyek, mereka melakukan secara efektif yaitu dengan elemen: Keterbukaan yaitu 
ODAMUN mau mengungkapkan sakitnya dan keluarga bisa memahami keadaannya. Empati, dalam hal ini dilakukan oleh anggota keluarga memberikan pemahaman dan pendampingian sehingga para ODAMUN semakin merasa dipahami keadaannya sehingga hal ini ODAMUN menjadi bersemangat untuk sembuh. Pada elemen dukungan para anggota keluarga selain prihatin juga memberikan pendampingan, dan melayani para ODAMUN dalam keperluannya saat kambuh. Rasa positif para penderita berusaha berlaku dan berpikir positif dalam menghadapi sakitnya. dan elemen kesetaraan, para ODAMUN dan keluarganya saling memberikan masukan dan mau menerima nasehat dari luar dengan tujuan untuk kesembuhan.

Mengetahui keluhan penderita autoimun yang paling menonjol adalah seperti nyeri sendi, mudah lelah, rambut rontok lemas tak bertenaga, dan tampak malas melakukan kegiatan, kulit merah panas, dan terjadi sariwan terus menerus. Pencetus utama saat kambuh pada autoimun ini adalah banyak pikiran yang mengakibatkan stress, sehingga imun para penderita mulai menyerang anggota tubuh. Solusi penderita autoimun dan anggota keluarga dalam menghadapi autoimun. Bagi ODAMUN konsultasi dokter yang merawat, mengelola stress dan berpikir positf. Sedang solusi bagi anggota keluarga lebih ke arah mendampingi, mendengarkan keluhan ODAMUN dan membawa ke dokter untuk berkonsultasi, serta membuat ODAMUN nyaman. Disarankan untuk penelitian lebih lanjut, untuk menguji berpikir positif apakah berpengaruh pada motivasi kesembuhan penderita autoimun. Sebagai pembelajaran dalam menghadapi keluarga yang menderita autoimun. Saran untuk masyarakat, supaya lebih aware terhadap keluarga atau orang yang menderita autoimun.

\section{DAFTAR PUSTAKA}

Agustinova, D.E. (2015) Memahami Metode Penelitian Kualitatif: Teori \& Praktik. Calpulis: Yogyakarta. ISBN: 978-602-73097-4-6

Alimuary, H. D. (2020). Analisis Program PT. JICT Rumah Belajar dalam Mendukung Indonesian Sustainable Development Goals 2018. COMMENTATE: Journal of Communication Management, 1(1), 37-46.

Aryadillah (2018) Komunikasi Antar Pribadi Dalam Keluarga (Studi Fenomenologi Terhadap Perilaku Komunikasi Pasangan Suami Istri Yang Mengalami Ketimpangan Jumlah Pendapatan). Cakrawala, Vol. XVIII, No 1, Maret, 2018

Bandura, A. (1986). Social foundations of thought and action: A social cognitive theory. Englewood Cliffs, NJ: Prentice Hall.

Baron, R. A dan Donn Byrne. (2003). Psikologi Sosial. Jakarta: Erlangga

Beebe, A. Steven \& Susan J. Beebe. (1996). Interpersonal Communication Relating to Others. USA: Sage Publication, Ltd.

Braithwaite, D. O. \& Schordt, P. (2014) Engaging Theories in Interpersonal Communication Multiple Prespectives ( $2^{\text {nd }}$ Edition). London: SAGE Publications. ISBN 978-1-45226140-9

Creswell, J. W. (1998). Qualitative Inquiry And Research Design Choosing Among Five Traditions. Sage Pubilcation, Inc. 
DeVito, J.A. (2018) Komunikasi Antarmanusia. Karisma Publishing: Tangerang. ISBN: 978979-583-909-5

DeVito, Joseph A. (2013). The Interpersonal Communication Book 13th Edition. United States of America: Pearson Education, Inc.

DeVito, Joseph, (1989), The Nonverbal Communication Workbook (Prospect Heights), illinois: Waveland Press.

Diantin, D.M.A., Ulandari, N.L., Wirandani N.K.N.S., Niruri R., Kumara K.D., (2016) Angka Kejadian Penyakit Autoimun Pada Pasien Anak Di Rsup Sanglah Denpasar, Jurnal Farmasi Udayana: Vol. 5 No. 2

Djaali. 2008. Psikologi Pendidikan. Jakarta: Bumi Aksara.

Effendy, Onong Uchajhana. (2003). Ilmu Teori dan Filsafat Komnikasi. Bandung: PT. AdityaBakti.

Endang Purwaningsih (2013) Depaertment of Anatomy, Faculty of Medicine, YARSI University Jurnal Kedokteran Universitas Yarsi, Vol. 21 (1) : 041-049

Gatra.com, 27 Juli 2019 21:18

Johnson, David W. 1981. Student-Student Interaction: The Neglected Variable In Education : https://doi.org/10.3102/0013189X010001005

Kanfer, R. (1992). Work motivation: New directions in theory and research. In Kerlinger, F.N. (1996). Foundations of behavioral research. Japan: CBS College Publishing.

Liliweri, A. (2015) Komunikasi Interpersonal (Edisi Pertama) (E-Book Digital Edition Version). Kencana: Jakarta. ISBN: 978-602-1186-43-5

Liliweri, A. (1991). Komunikasi Antarpribadi. Bandung : PT.Citra Aditya Bakti

Locke, E.A., \& Latham, G. P. (1990). A. theory of goal setting and task performance. Englewood Cliffs, NJ: Prentice Hall

Mangkunegoro, AA Anwar Prabu. 2009. Management Sumber Daya Manusia. Bandung: PT Remaja Rosdakarya

Moleong, L.J. (2010) Metodologi Penelitian Kualitatif [E-Book Digital Edition Version]. Remaja Rosdakarya: Bandung. ISBN: 979-514-051-5

Morissan. (2013) Teori Komunikasi: Individu Hingga Massa (Edisi Pertama) (E-Book Digital Edition Version). Kencana: Jakarta. ISBN: 978-602-9413-68-7

Mulyana, Deddy. (2000) . Ilmu Komunikasi Suatu Pengantar. Bandung: PT. Remaja Rosdakarya

Ngalimun, (2018). Komunikasi Interpersonal (Cetakan 1). Yogyakarta: Pustaka Pelajar. ISBN: 978-602-229-903-5

Nurhadi, Z.F. (2015) Teori-teori Komunikasi: Teori Komunikasi dalam Perspektif Penelitian Kualitatif. Ghalia Indonesia: Bogor. ISBN: 978-979-450-691-2

Pinder, C.C. (1998). Work motivation in organizational behavior. Upper Saddle River, NJ: Prentice Hall. 
Prathiwi, G. L. A. (2020). Analisis Kendala Penggunaan Bahasa Dalam Pekerjaan Pada Masyarakat Sunda. COMMENTATE: Journal of Communication Management, 1(2), 129-147.

Rahmat, Jalaludin, 2009, Psikologi Komunikasi, Bandung, PT.Remaja Rosdakarya.

Salvicion dan Celis. (1998). Bina Keluarga. Terjemahan. Jakarta:Rineka Cipta

Siloam Hospital, 13 Maret 2011 “Seminar tentang Autoimun”

Sugiyono. (2015) Metode Penelitian Pendidikan: Pendekatan Kualitatif, Kuantitatif dan R\&D. Alfabeta: Bandung. ISBN: 979-8433-71-8

Sugiyono. (2011). Metode Penelitian Kuantitatif, Kualitatif dan R \& D. Jakarta: Alfabeta

Sugiyono. (2010). Metode Penelitian Pendidikan Pendekatan Kuantitatif, kualitatif, dan R\&D. Bandung: Alfabeta

Sumantri, Rita Fahdila. 2012. Kompetensi Pengelolaan Pembelajaran, Kecerdasan Interpersonal, Komitmen, dan Kepuasan Kerja Guru SMK. Jurnal Ilmu Pendidikan. 18(1): $30-35$

Sumantri, S. (2012). Perilaku organisasi. Bandung: Universitas Padjadjaran.

Suranto. AW. (2011) Komunikasi Interpersonal (Edisi Pertama). Graha Ilmu: Yogyakarta. ISBN: 978-979-756-771-2

Uno, H. B. (2008). Teori Motivasi \& pengukurannya. Jakarta: PT Bumi Aksara.

Widodo, Tri. (2006). Perencanaan Pembangunan. Aplikasi Komputer (Era Otonomi Daerah). UUP STIM YKPN. Yogyakarta.

Wiryanto. (2004). Pengantar Ilmu Komunikasi. Penerbit PT. Gramedia Widiasarana Indonesia. Jakarta.

Yusuf, M. (2014) Metode Penelitian: Kuantitatif, Kualitatif \& Penelitian Gabungan. Prenadamedia Group: Jakarta. ISBN: 978-602-1186-01-5 